\title{
Greening and opening the public space of the Nile banks. A demonstration case study in Maadi, Cairo
}

\author{
Amir Gohar \\ University of California Berkeley, United States of America \\ Department of Landscape Architecture \& Environmental Planning \\ amir.gohar@berkeley.edu
}

\begin{abstract}
The Nile, in general, and particularly in Cairo, is an ecological, cultural and social corridor that is not yet fully utilized. The 20II Cairo workshop "Connecting Cairo to the Nile" identified the potential to increase accessibility to the river, suggested longitude trail system, proposed connecting the waterfront with adjacent neighborhoods and proposed expanding the ferry system. I studied a $2-\mathrm{km}$ reach of the east bank in Maadi, a wealthy suburb about $10 \mathrm{~km}$ upstream of the city center, with relatively greener banks, availability of resources at the district level, higher awareness of local residents, physical setting allow for banks re-use, existence of community organizations (i.e. Tree Lovers and Midan). Findings of fieldwork and interviews show that: (i) species of native vegetation found are Phoenix Dactylifera, Jacaranda, Cortedarea and Papyrus alba; these are concentrated along II 5 meter in southern part of the study area. (ii) Public access was categorized into: public space (accessible), private or semipublic space (accessible with conditions), and prohibited (inaccessible). Along this representative stretch of the Nile, the public access was limited to $16 \%$, the private or semipublic makes $29 \%$ and the prohibited zones are $55 \%$. (iii) Boating operations found to be in three categories, floating hotels (Nile cruises), motor boats (including ferries) and sailing boats, all are scattered along the banks without an overall plan or organization, which affects water flow and block public access to the banks. To better develop the banks, I recommend (i) maintaining existing riparian vegetation and expand it to other areas with healthy banks or planted nurseries, (ii) connecting open public spaces to create a pleasant walking trail along the banks in addition to improving public access by relocating government buildings (such as the police or military facilities) and facilitate access to the river for general public, (iii) reducing the anchoring points to two locations and redistribute boating operations to group all motor boats to use the ferry anchoring points and all the sailing boats to use Al-Yacht club marina.
\end{abstract}

Keywords: public space, landscape, Nile accessibility, Cairo, Egypt

\section{To cite this article:}

Gohar, A. (2018). Greening and opening the public space of the Nile banks. A demonstration case study in Maadi, Cairo. The Journal of Public Space, 3(I), 3I-48, DOI: 10.5204/jps.v3iI.3I7

This article has been peer-reviewed and accepted for publication in The Journal of Public Space. Please see the Editorial Policies under the 'About' section of the journal website for further information.

This work is licensed under a Creative Commons Attribution - Non Commercial 4.0 International License https://creativecommons.org/licenses/by-nc/4.0/ 


\section{Introduction}

Cairo suffers from massive urbanization, blocked traffic, informal housing, inefficient public transportation, highly congested movement corridors, insufficient public space, and almost no green cover.(AlSayyad, 20I I; El Araby, 2002; G. M. Kondolf, Mozingo, Gohar, \& Marzion, 20II; Sabry, 2010; Sims, 2012). Urban projects along the Nile in Cairo have always focused on the beautification of the banks to provide an enhanced view for city users, and some of these projects include public landscape architecture elements. Very little attention has been given to the river ecosystem and the public's access as main users of the city (Gabr, 2004; M. Kondolf, Gohar, Mozingo, Marzion, \& Balakrishan, 20I3) The Nile corridor is an opportunity that is not fully realized to improve the quality of life for the city, if looked at beyond being a scenic view but rather an environmental stream with multiple urban, ecological, and social opportunities.

The aim of this research is to illustrate a sustainable long-term pilot project for a segment of the Nile in Cairo, which can inform future development along the Nile.

The "Connecting Cairo to the Nile" workshop report and paper have been presented in several conferences such as: ASLA Phoenix 20I2, Cairo SBI3 2013, and Cairo CCN 2017 are shown in figure $\mathrm{I}$.
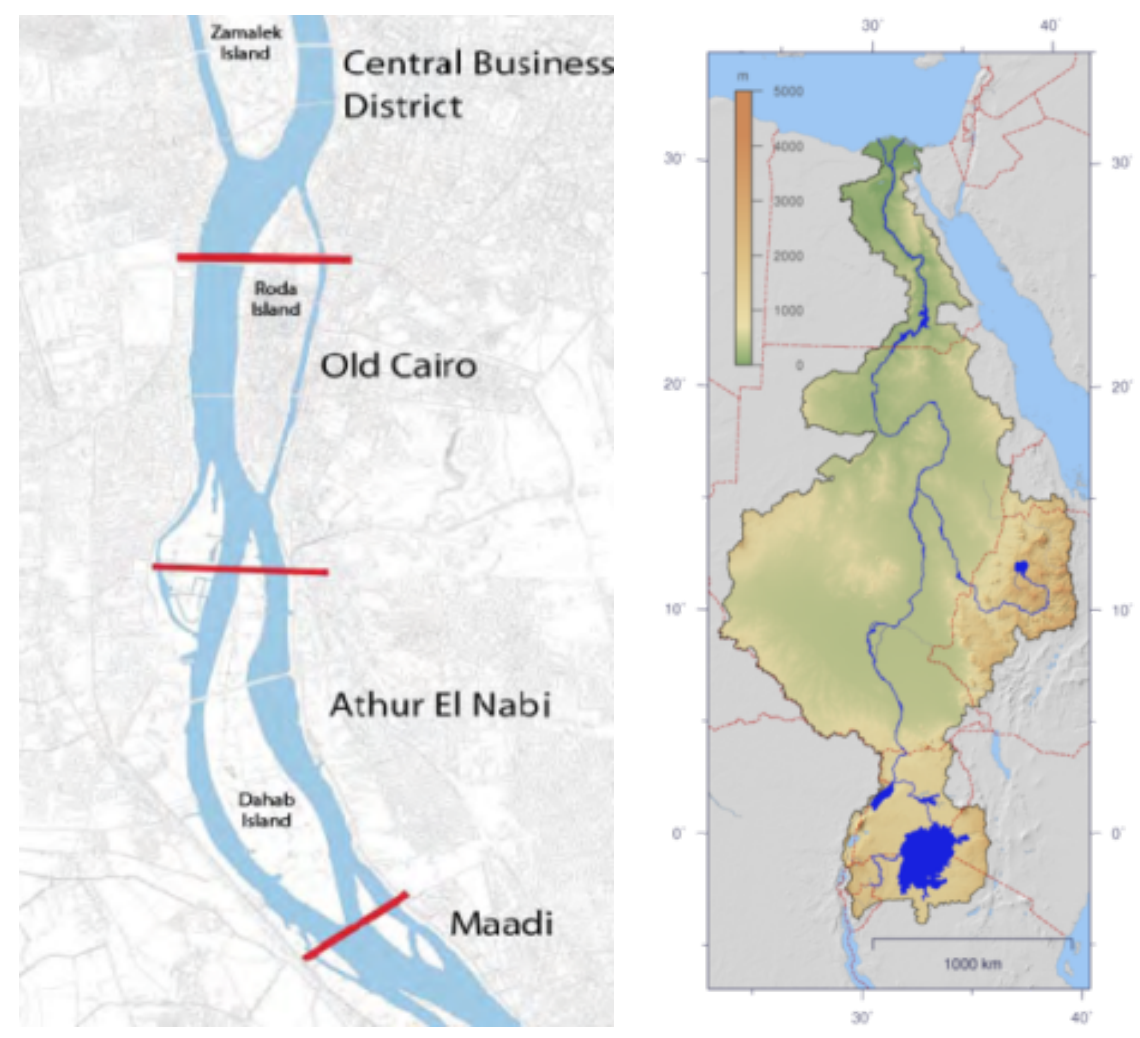

Fig. I. The four study zones in Cairo workshop 201 I (source workshop report). Fig. 2. The Nile from Victoria Lake to the Mediterranean.

The workshop/report addressed: developing a continuous path along the river bank; accessibility to the river; reconnecting adjacent neighborhood to the water front; greening" of the banks; and expanding the ferry system. However, the $201 \mathrm{I}$ report did 
not fully address: riparian vegetation; detailed assessment for the selected site in Maadi; boating operations and possibilities to improve it; and potential noise reduction across Maadi stretch.

Maadi, the last segment south was selected as case study site for the workshop, because it is considered a wealthy suburb about $10-\mathrm{km}$ upstream of the city center, with relatively greener banks, availability of resources at the district level, higher awareness of local residents, and its physical setting allowing for banks' re-use, and existence of community organizations (i.e. Tree Lovers and Midan).

\section{I.I. Nile Basin Background}

The Nile is the longest river in the world $(6,695 \mathrm{~km})$, the total length of the river and its tributaries equals 37,205 km2. The Nile's catchment's area: 2.9 million km2 shared among eleven countries: (Burundi, Democratic Republic of Congo, Egypt, Ethiopia, Eritrea,

Kenya, Rwanda, Sudan, South Sudan, Tanzania and Uganda). The total population of these countries is about 280 million (El Araby, 2002; Kassas, 197I). Figure (2) shows the Nile from its Victoria lake to the Mediterranean with the magnitude of its watershed.

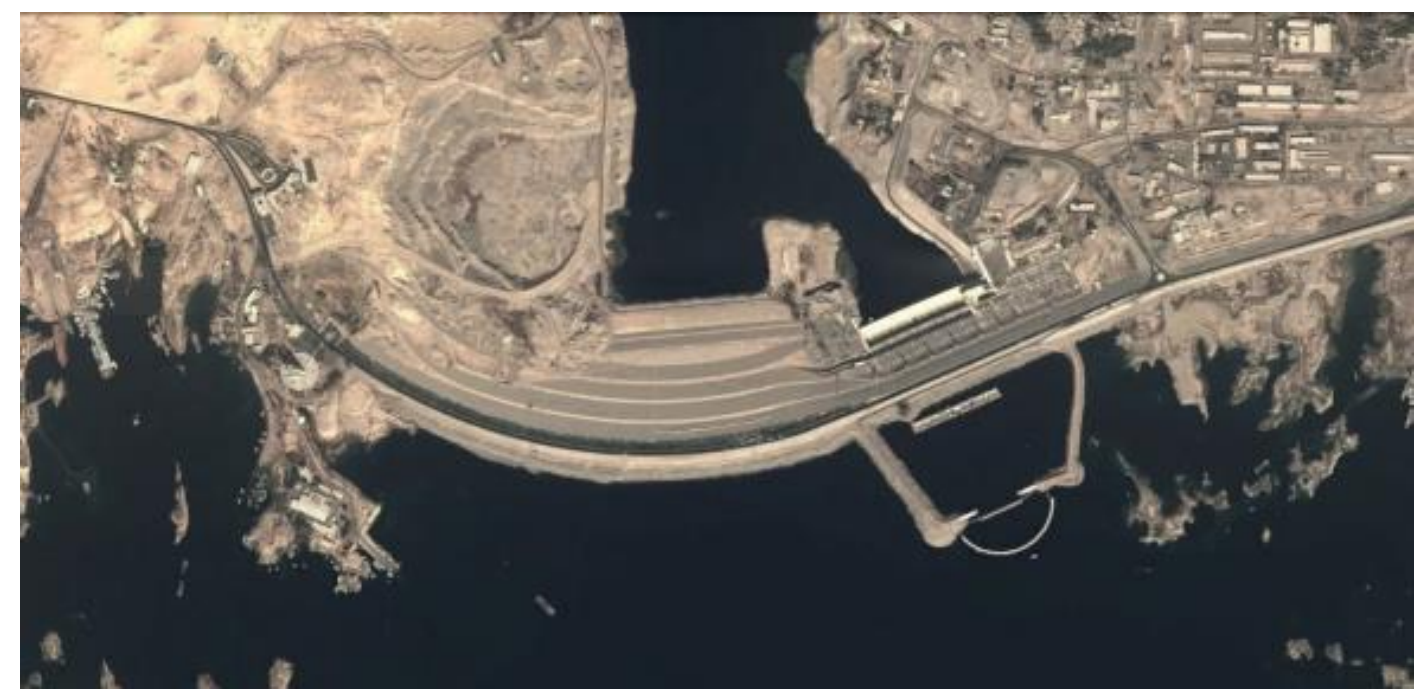

Fig. 3. Current plan views for the Aswan High Dam and the Northern part of Lake Nasser (Source, Google).

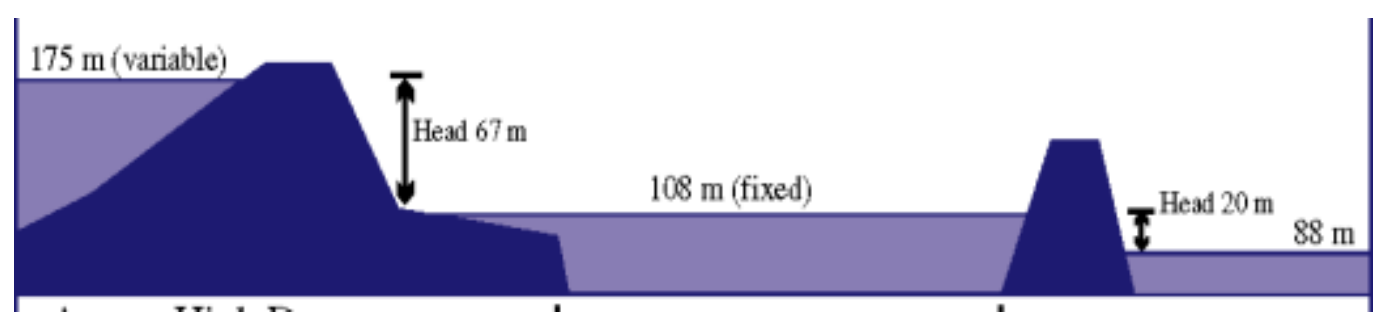

Fig. 4. Cross section showing the two Aswan Dams (Source Sayed El Sayed, Texas A\& M University).

The most significant intervention on the Nile in Egypt is the High Aswan dam. While the dam was put in place to promote/enhance year-round agriculture production, retention of sediment has dramatically reduced nutrient value in floodplain. It was viewed by some scholars as a symbol of progress, others see it as a major drawback in terms of the river's 
ecological integrity (El-Shibini \& Rydzewski, 1977). AbuZeid and El-Shibini ( 1997) argues that the High Aswan Dam is the main source for sustainable irrigation, hydropower and navigation improvement. They also confirm that the dam has saved Egypt twice: (a) from a dangerous flood series, which occurred in the late 1970s, and (b) from severe droughts in the mid-1980s. Other scholars see the Aswan high dam as an obstacle to ecological process. Rosenberg (2017) confirms that before the building of a dam at Aswan, Egypt experienced annual floods from the Nile River that deposited four million tons of nutrient-rich sediment, which enabled agricultural production.

This process commenced millions of years before Egyptian civilization began in the Nile valley, and continued until the first dam at Aswan was built in 1889. This dam was insufficient to hold back the water of the Nile and was subsequently raised in 1912 and 1933. In 1946, the true danger was revealed when the water in the reservoir peaked near the top of the dam. Figure 3 shows a current plan view for the Aswan High Dam, and figure 4 shows its relation with the initial small dam that is further north.

The level of water in the Nile at the high damn has an average of $147 \mathrm{~m}$ (Ministry of Water Sep.2013). The High Damn Authority confirms that the water behind the damn is 120 million $\mathrm{m} 3$ and the water in Lake Nasser is also calculated to be $120 \mathrm{~m} 3$.

\subsection{The Study Area, Cairo \& The Nile}

Very little attention has been paid to the river ecological dynamics or the banks, especially that the ecological restoration projects might be visually less appealing, according to a study by Gabr (2004). Tackling the banks' design and people's reaction to water front development, shows that the general public are concerned by losing the visual contact with the river as well as the degradation of the banks aesthetics. The river is running across the city as shown in figure 5 and it is the most significant corridor in the city.

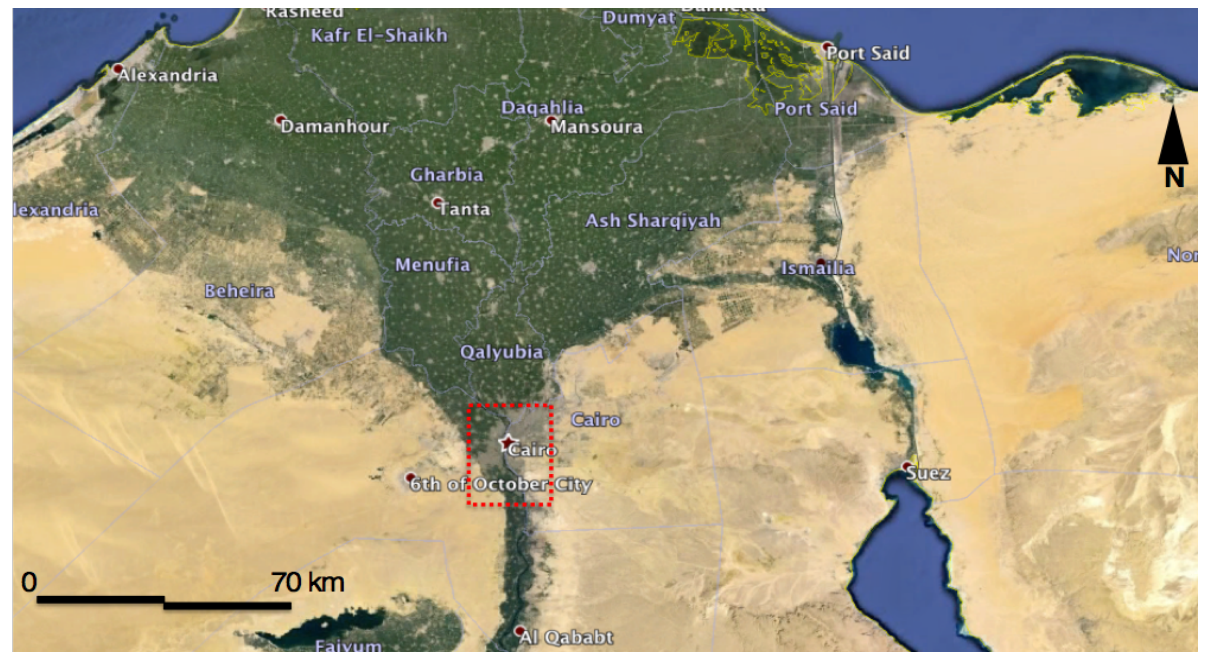

Fig. 5. Cairo and the Nile.

Maadi is an affluent suburb in the south of Cairo, Egypt. The town is home to the Supreme Constitutional Court of Egypt, Lycée Français du Caire (LFC), Cairo American College (CAC), Maadi British International School (MBIS), the Cairo Rugby Club, and the 
national Egyptian Geological Museum. Maadi is also home to the Maadi Sporting Club, founded in 1920 by the British Expats who were mainly working at the Delta Real Estate Company. The selected study area is located in Maadi which is also known for some remaining ecological integrity. This is evident in higher concentration of trees relative to the rest of the city.

The $2 \mathrm{~km}$ study area extends from the military hospital north to Al-Adra historic Church south. Figure 6 (top) shows shows the location of the selected stretch of the Nile (Maadi) within Cairo, (bottom) shows the project extent.

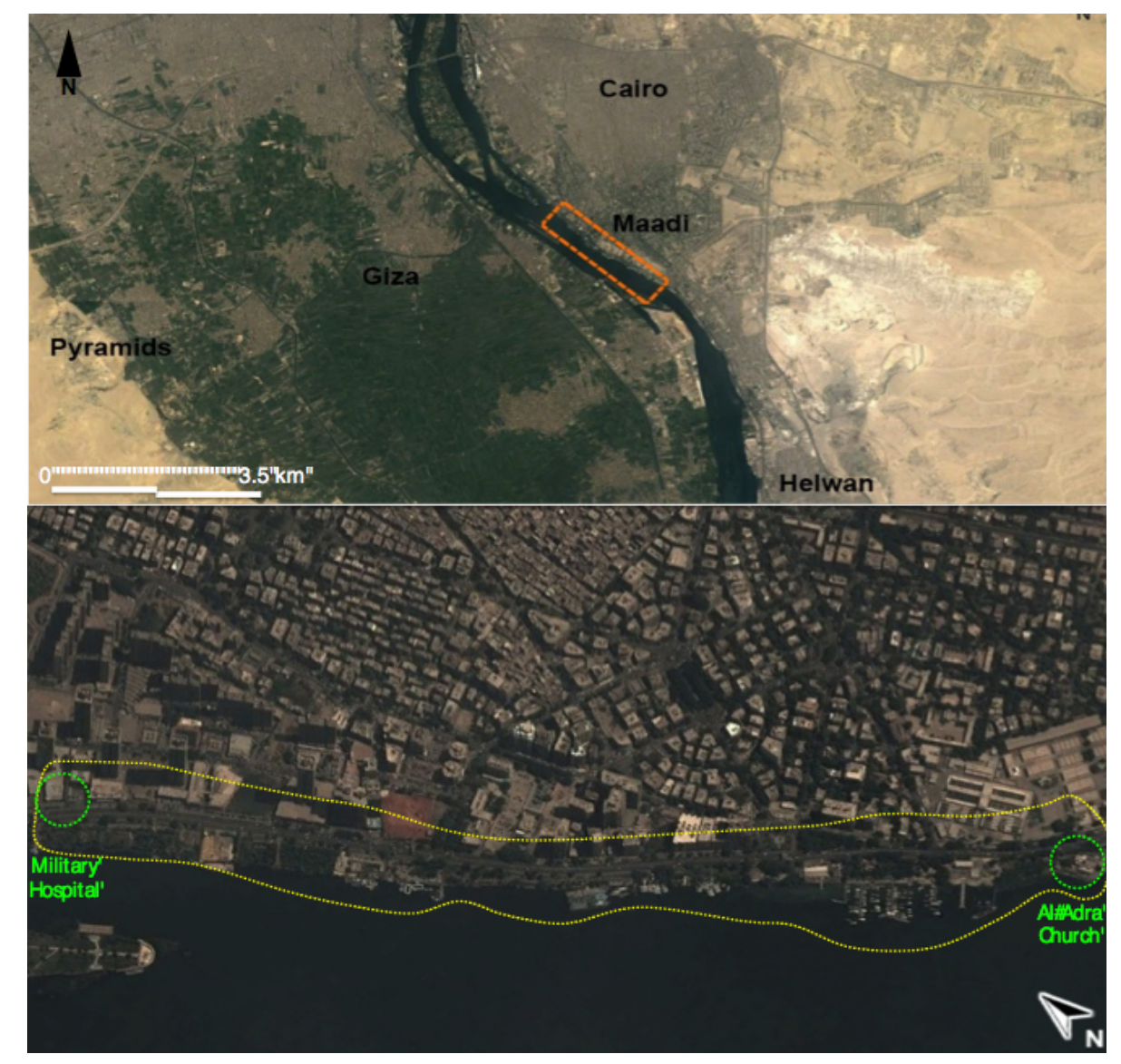

Fig. 6 (top) Image showing the location of the study area within Cairo context; (bottom) the study area extent.

\section{Research problem}

\section{I. Research Question}

Within the current business-as-usual, urban development will continue taking place in an ecologically harmful manner resulting in loss of riparian vegetation, stress on the banks, loss of public access to the river and encroachments on water front (G. M. Kondolf et al., 20I I; M. Kondolf et al., 20I3). Booth (2005) and Bernhardt (2007) assert that it is important to realize that the restoration of dense urban rivers to its very original condition is almost impossible. The Nile in Cairo is no different, especially with the current dense urban development and the existence of the high dam. However, the goal of this pilot study is: to explore and examine different possibilities to improve the bank 
condition, achieve public access to the river, and enhance the boating operations along the stretch.

While very little has been written on the quality of public space in conjunction with ecological status on the Nile, the literature identifies numerous factors that are used to measure the social and environmental quality of public space. Malone (2002), Zhang (2016) and Mehta (2014) confirm that the quality of the public space is determined socially by its accessibly, democratic use and quality of design. They equally assert that environmental qualities such as maintaining ecological integrity, protection of resources and reduction of solid improves the quality of the built environment for users.

In Cairo, and specifically in this study area, the applicable factors that are found to improve the quality of the public space and intersect with the environmental quality and waterfront improvements are riparian vegetation, boat operation, accessibility to the river and the use of the banks (El Araby, 2002; Gabr, 2004; Gohar, 20 I6; G. M. Kondolf et al., 20II; M. Kondolf et al., 20I3)

\subsection{Research Limitations}

Ideally, any suggested water-front recommendations or restoration-based actions on the Nile would be part of a larger framework addressing the entire river. However, such research is the mandate of the Nile Basin Initiative (NBI), which is the organization responsible for coordinating all Nile related activities between the 10 member countries. It suffers lack of resources and un-coordinated management by representative countries. The dense urban fabric around the river limits ecological restoration of the river banks. There might be some challenges by government agencies that have planned for Cairo (i.e. Cairo 2050 plan) which have very little consideration to the river as ecological stream.

\section{Methods (field work)}

A combination of field observation and boat operators interviews was adopted to provide a measure for the extent of each factor and its impacts of the urban quality of public space. The survey of the bank shows that they are occupied by several uses; the most significant ones are listed below from South to North:

I - Al-Adra Church

2- Water company extension

3- MAADI Yacht Club

4- Private Restaurants: Fridays/Fish Market/Grand Café

5- Sailing Boats Jetty (Felouka)

6- Sailing Boats Jetty (Felouka)

7- Nile Cruse Station

8- Ferry building

9- Nile Police Service

10 - Government Building

The map in figure 7 shows the main activities on the bank in the study area, with the permanent concrete structures in red and the light structures in yellow. The remaining are nurseries, open spaces or abandoned lands that are mostly inaccessible by public. 


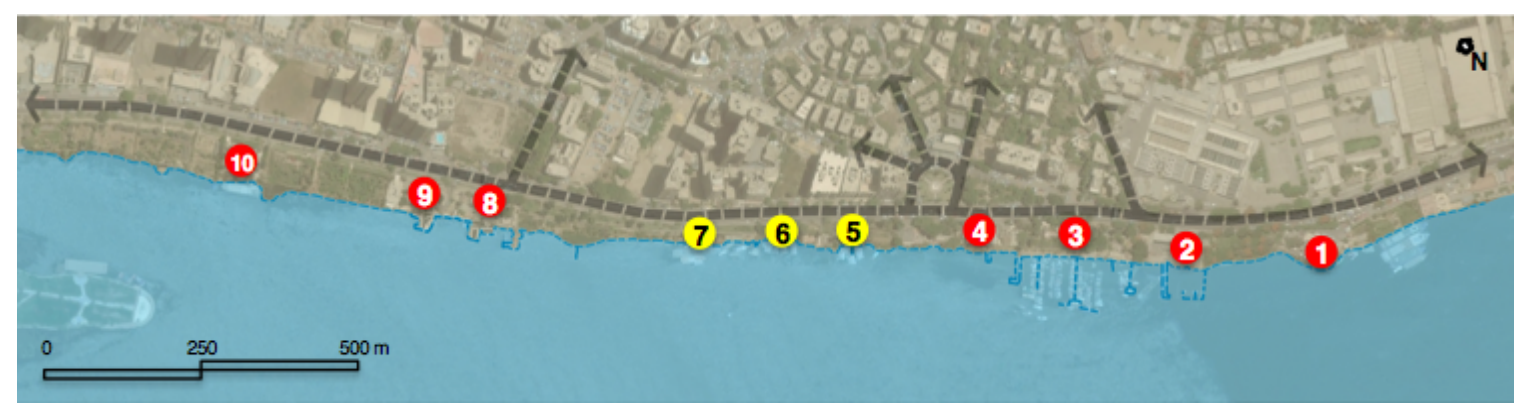

Fig. 7. Activities with fixed structures the banks.

\section{I.Vegetation}

Most of the noticed vegetation on the river is introduced as part of the streetscape or by owners/users of the bank, such as the Ficus Nitidatrees and some palm trees. However, the most common native plants found in the study areas are in the table below.

\begin{tabular}{c|l} 
Vegetation Shape & Species \\
\hline I. Palms trees & Phoenix Dactylifera \\
\hline 2. Trees Jacaranda & Jacaranda \\
\hline 3. Pampas Grass & Cortedarea \\
\hline 4. Papyrus Grass & Papyrus alba
\end{tabular}

Table I. Riparian vegetation types in the Maadi area.

The map in figure 8 shows the vegetated zones in the study are (top), a close-up on riparian vegetation (middle) and picture of types of vegetation (bottom).

In absence of proper sedimentation in the river because of the High Aswan Dam that is explained earlier, banks remain vulnerable to erosion. Although this stretch has no concrete edges, the riparian vegetation seems to be very effective in maintaining the banks along this stretch.

\subsection{Boat Operations}

Boating can be classified into three main types according to the size of the boat:

(a) The mega Nile cruise or the floating hotels that hypothetically takes tourists from Cairo south to Luxor and Aswan, while they are standing still as floating places for leisure (i.e. restaurants and cafes). In this stretch of the Nile seven cruises are parking and with no anticipated plans to park elsewhere as in figure 9 . This phenomena impacts the water flow near the banks, are visually unpleasant and limit the use of the river to certain business groups. 
Greening and opening the public space of the Nile banks
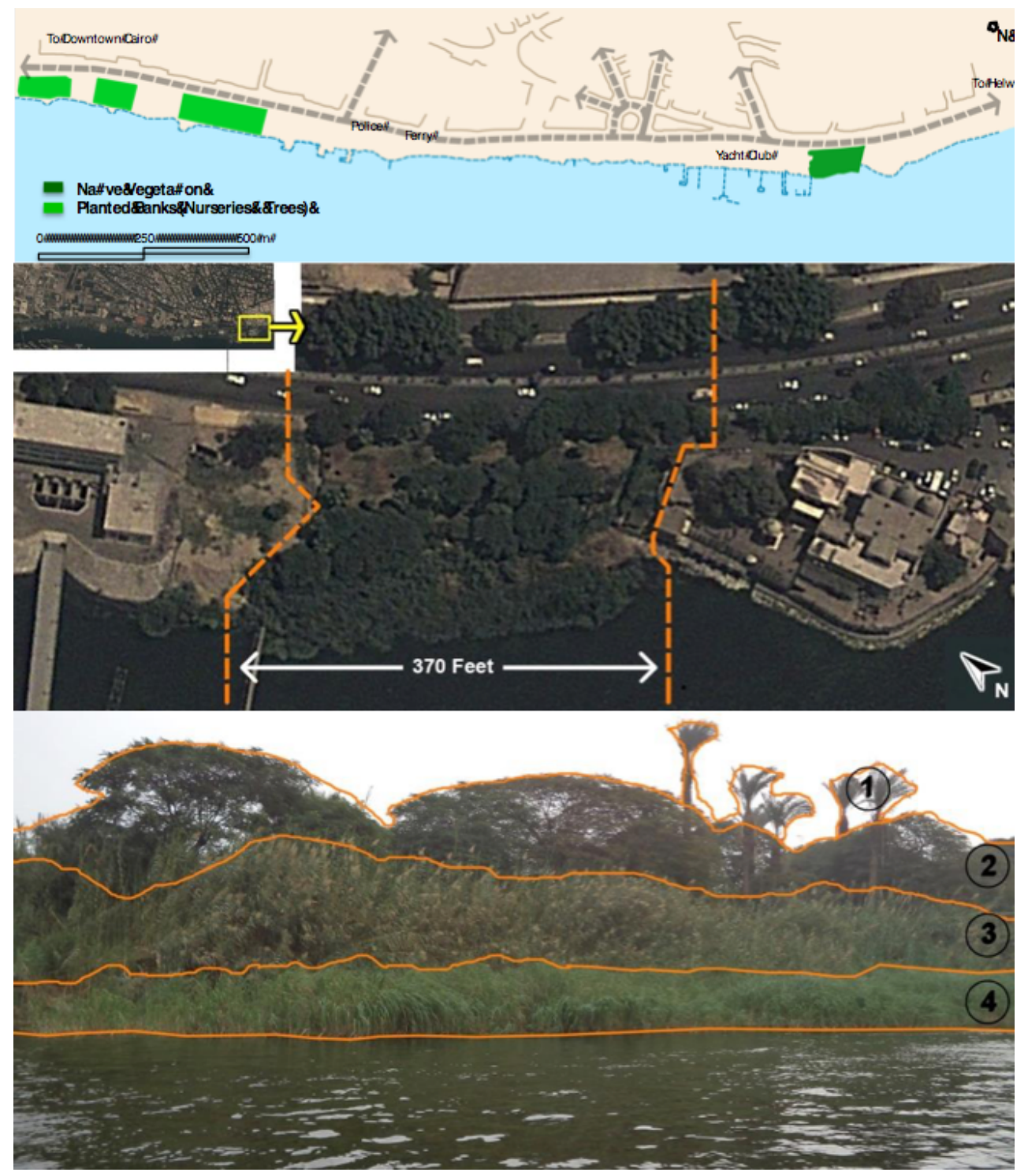

Fig. 8. Location of vegetation to the top, picture of vegetation to the bottom.
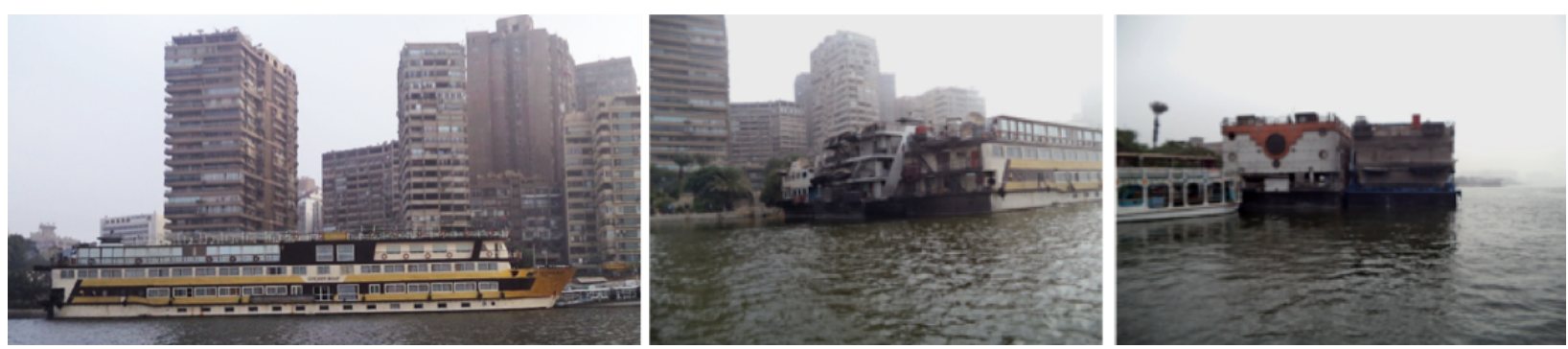

Fig. 9. Nile Cruses.

(b) Smaller than the above type yet still motor boats are the police marina and ferries that takes residents to the other side of the bank, with a cost of 50 piasters for the individual. These motorboats, shown in figure 10 are scattered along the river 
without a comprehensive plan and locations can be better aligned or grouped to reduce air pollution, water pollution and noise.

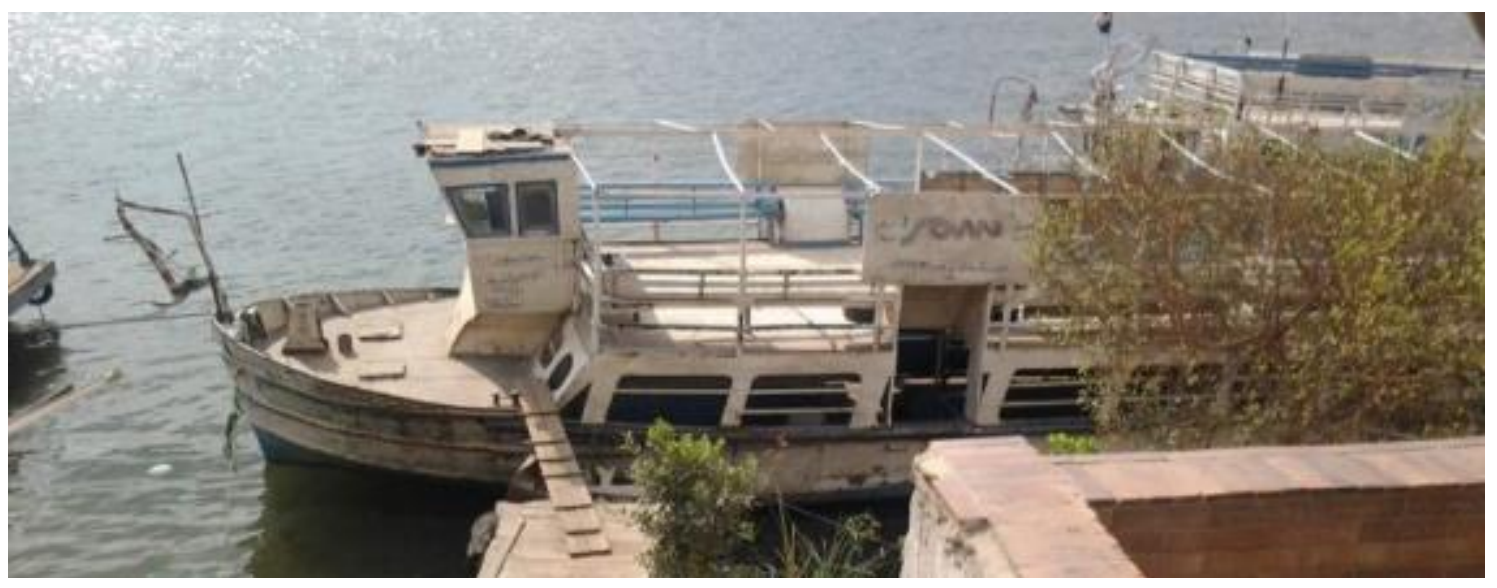

Fig. 10. Motor Operating boats (i.e. medium size tourist, police boats, ferry).

(c) The sailing boats, which are used for casual daily tours within Cairo, are rented by the hour for leisure. Figure II shows few boats anchoring to each other. This category includes private sailing/sports boats used by private owners (mainly located in el-Yacht Club). The map is figure 12 shows the location and the distribution of the above three types of boat operations in this representative stretch.

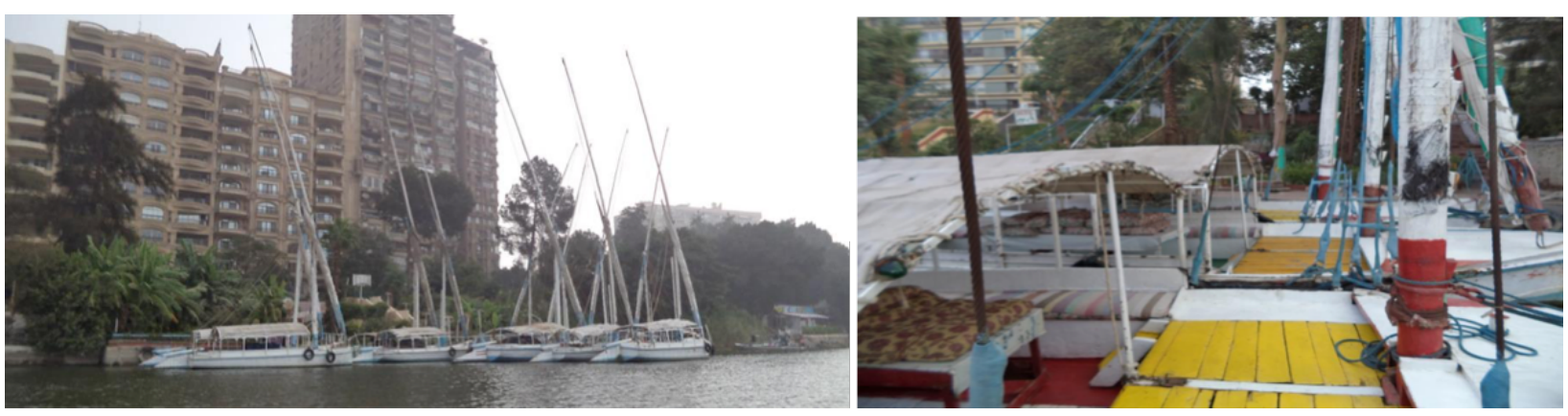

Fig. II. Sailing boats for short tours.

In addition to field survey, it was essential to have a sense of the recent boating operation patterns, which cannot be captured in one visit. The interviewed boat operators (Mr. Ahmed \& Mr Farag) had almost the same views about the current situation. They confirmed no operations for the Nile cruses in general and especially due to the recent political change in Cairo. The sailing boats (the Folouka) are mainly operated by people who are hired and not necessarily on monthly salary, but rather making a small percentage of the daily income from the tours (which are limited) and also tips from the customers. The interview revealed that the ferry is not inviting to majority of Egyptians due to its low quality and disconnect with other public transport system, which is also confirmed by a research on public transport by Mahdy (20I2) who asserted that the ferry users are not more than $0.57 \%$ as in the diagram in figure 13 . 


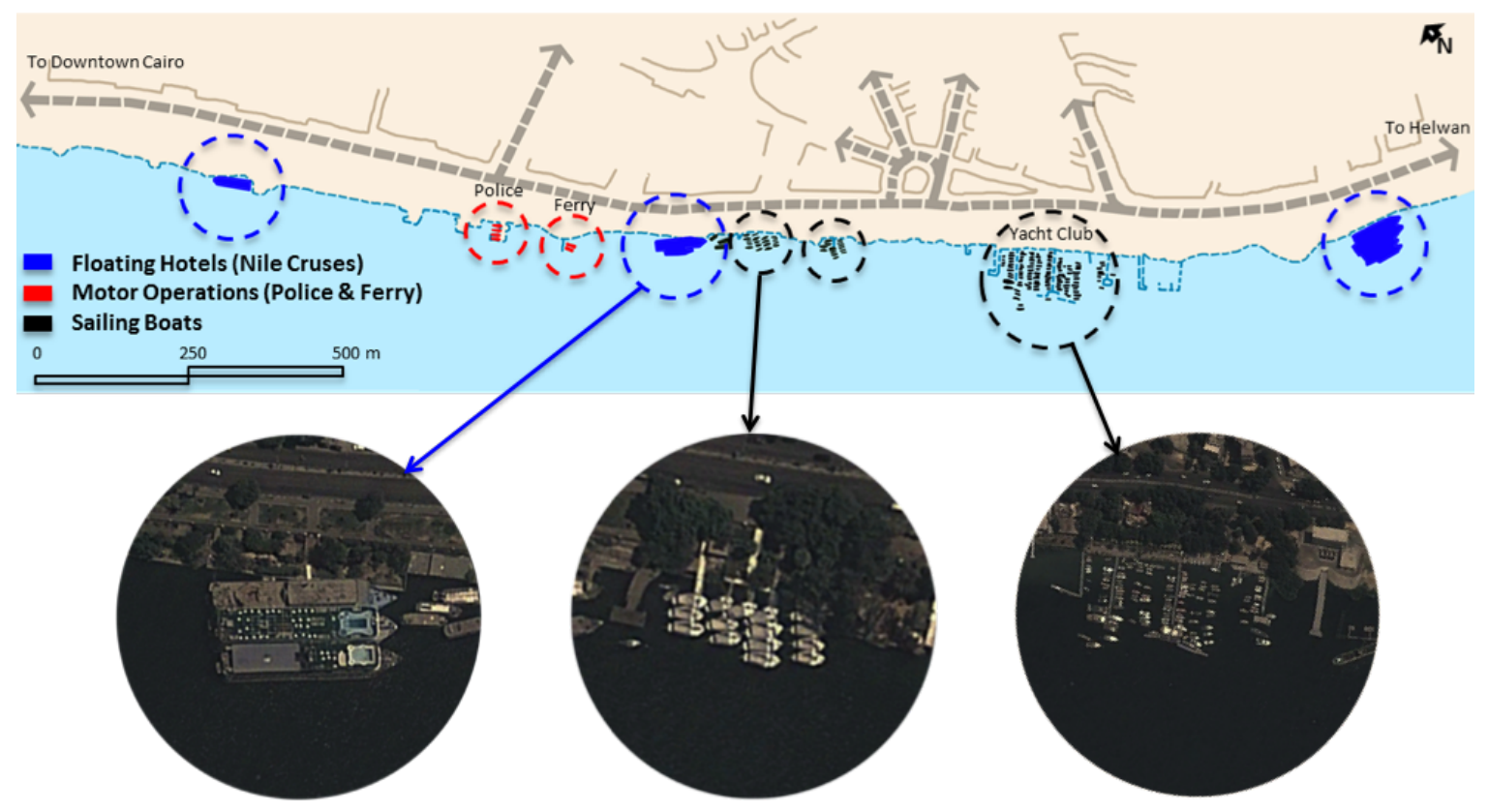

Fig. 12. The distribution of different types of boat operations in this stretch of the Nile.

Buses
Mini-buses
Air conditioned buses
Tram
Metro
Nile ferries

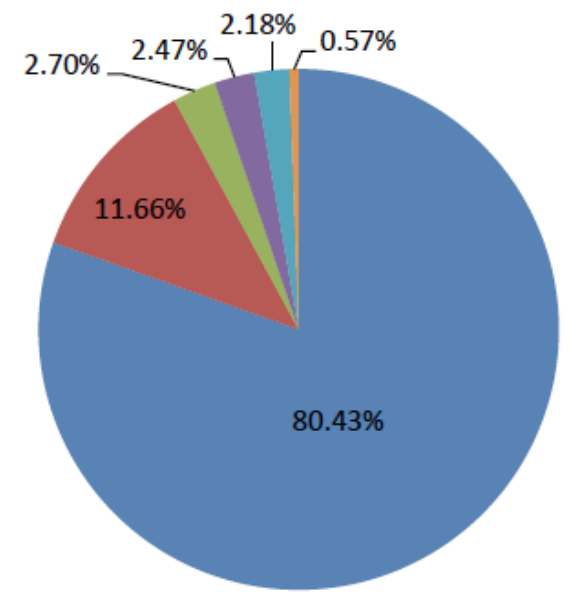

Fig. 13. percentages of uses for different transportations in Cairo.

\subsection{Accessibility}

Ethnographic research for old pictures of Maadi along the corniche is used to identify how the banks were utilized in the past. The images found shows that there has been more direct access to the Nile as a public domain. Figure I4-A shows (Al-Adra Church) looking north and how the road was not separated from the Nile while its current picture shows fence, parking area and some street trees blocking the access to the river. Figure I4-B shows a picture from the edge of the river (the sidewalk) looking southward. Figure 14-C is a picture from Misr-Helwan road, and although it doesn't show the water directly, it shows that the road visual connection to the riverside without the current dense urban 
development. The location of the archival images is anticipated to be as shown in figure 15.
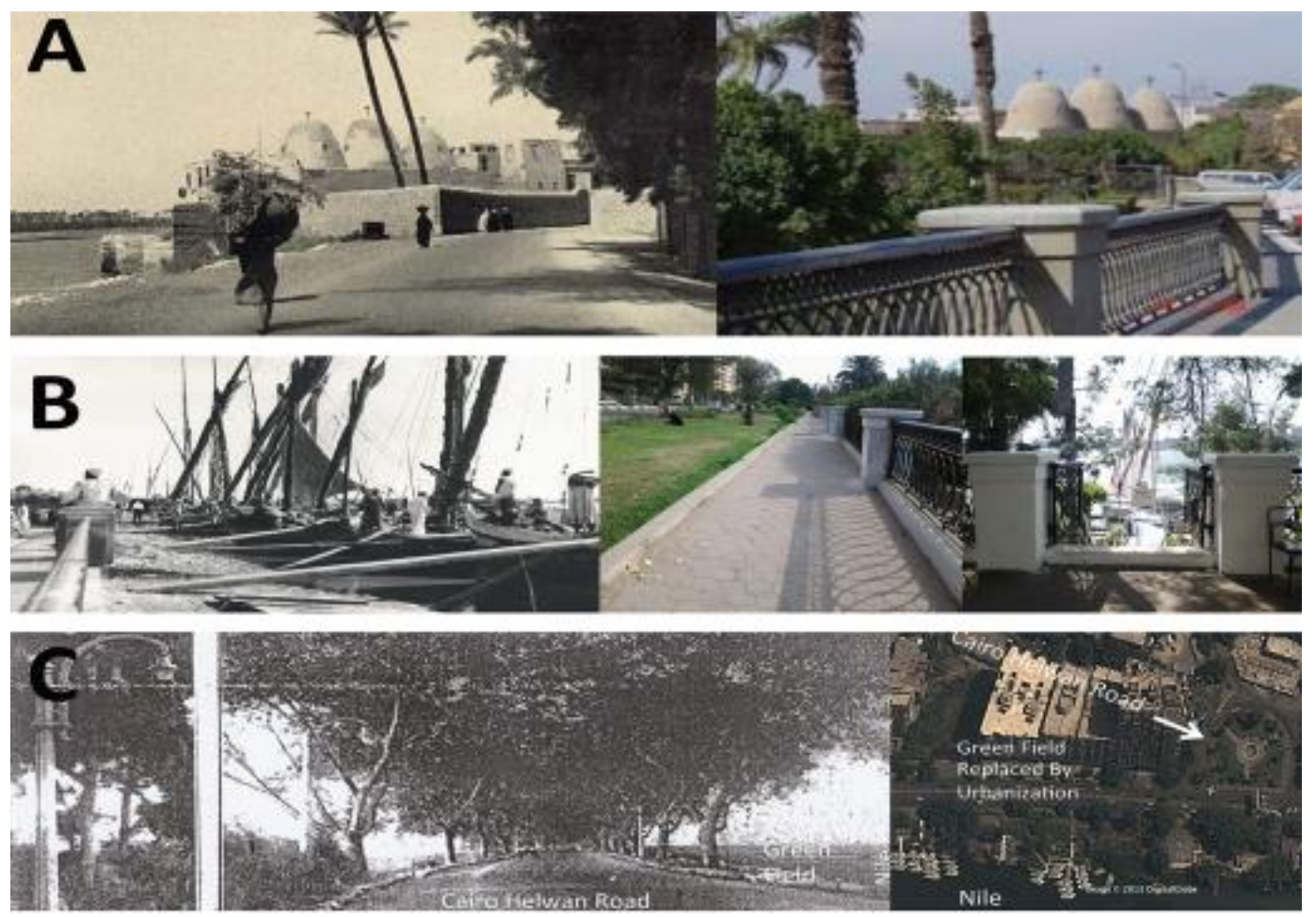

Fig. I 4. Different images comparing the change of public access from past and today.

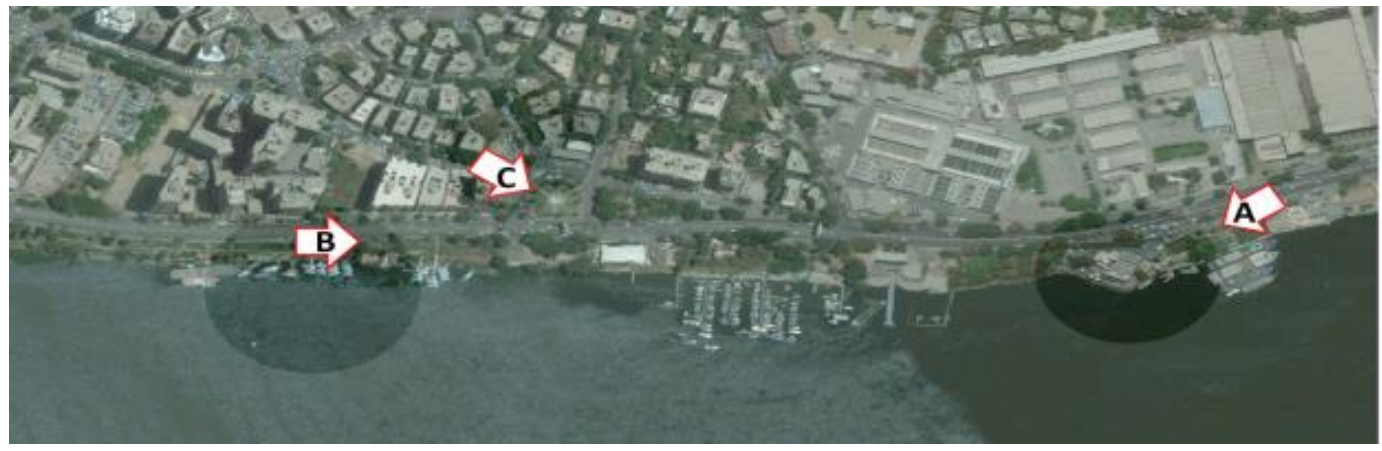

Fig. 15. Images showing the location where the images above were taken.

The study area is $(2 \mathrm{~km})$ in length and it is not all accessible to the public for different reasons. The entire banks were surveyed and classified into three categories:

a) Public Space (Accessible): these are the zones that do not prevent any individual of the public to access the Nile. Such as areas with no uses between the main street and the river.

b) Private or Semi Public space (Accessible with conditions): these are the zones of the Nile where there is development occupying land between the main street and the water, and it is semi-public because it is accessible to the public with conditions, such as restaurants that apply a high minimum charge that prevent some socioeconomic classes from reaching to the Nile. Another example is the yacht club, which requires a 
specific membership that most of Maadi residents have, but other Cairo residents do not necessarily enjoy.

c) Prohibited Space (Inaccessible): These are the areas that are not accessible at all and prevent the people from reaching to the Nile. These are either private lands such as planting nurseries or military services. Figure 16 shows these three categories along the study segment. Along this representative stretch of the Nile, the public access was found to be limited to $16 \%$, the private or semi-public makes $29 \%$ and the prohibited zones are $55 \%$ as shown in figure 17.

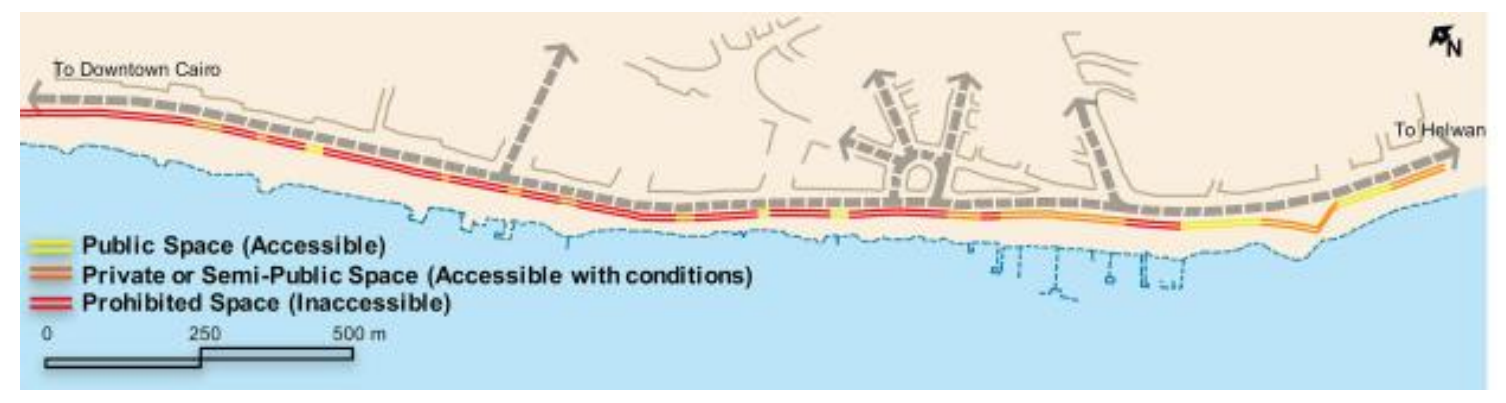

Fig. I6. Accessibility into three categories: (i) accessible, (ii) conditionally accessible, (iii) inaccessible.

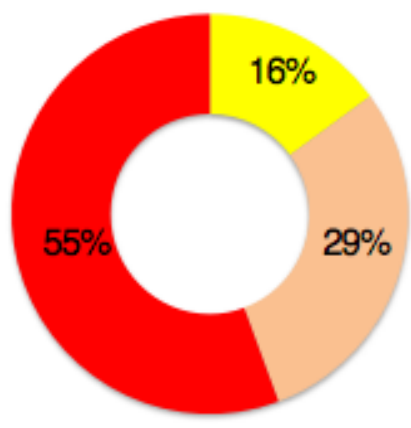

Public (Accessible)

Pivate or Semi-Public (Accessible with conditions)

Prohibited(Inaccessible)

Fig. I7. Percentage of accessibility to the water in a linear stretch.

The set of images in figure 18 shows different examples of physical barriers that are installed to prevent the general public from accessing the river.
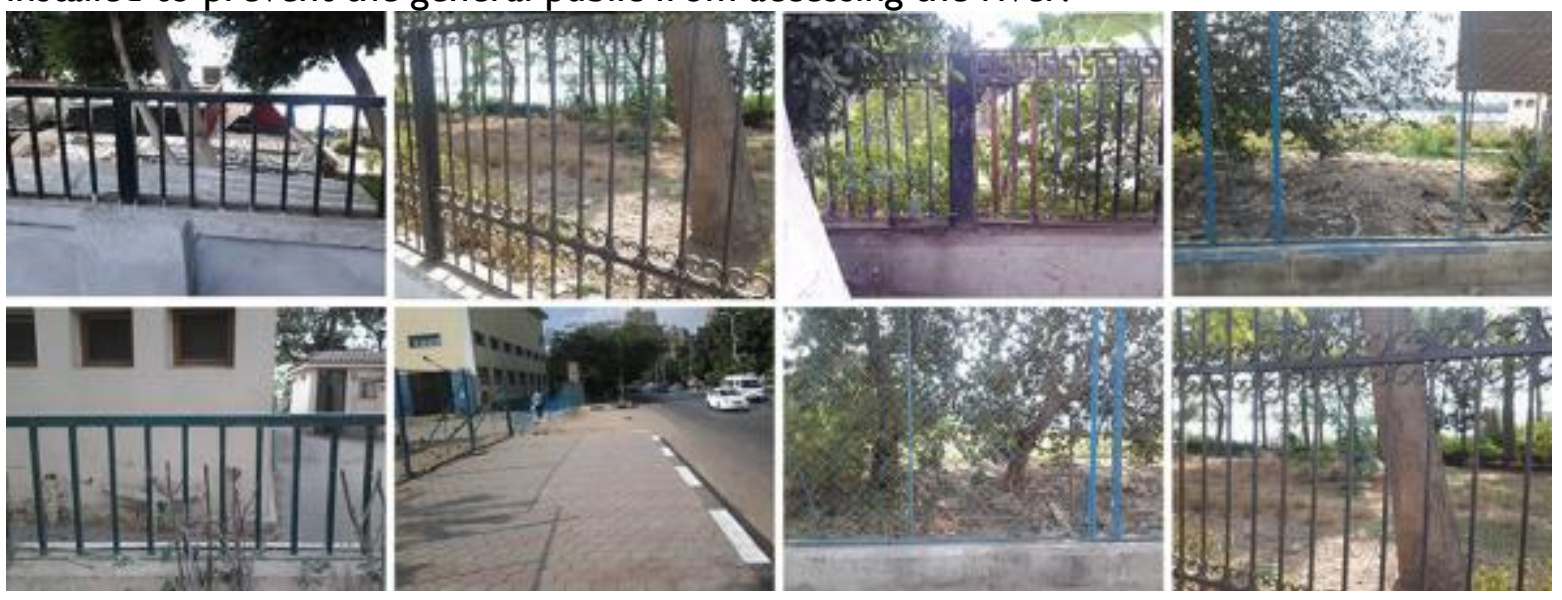

Fig. 18. Examples of physical barriers that prevent public access to the river

42 | The Journal of Public Space, 3(I), 20I8 | ISSN 2206-9658

City Space Architecture / Queensland University of Technology / UN-Habitat 


\subsection{Other Cross Cutting Findings}

\subsection{Informal Occupation}

Informal encroachment in Cairo is not limited to the urban encroachment on agriculture land, but extend to floating boats occupation of the sides of the river The image in figure 19 shows an example of two families living permanently in these two boats and using the Nile as a permanent base to pursue all daily activities as well as overnight sleep.

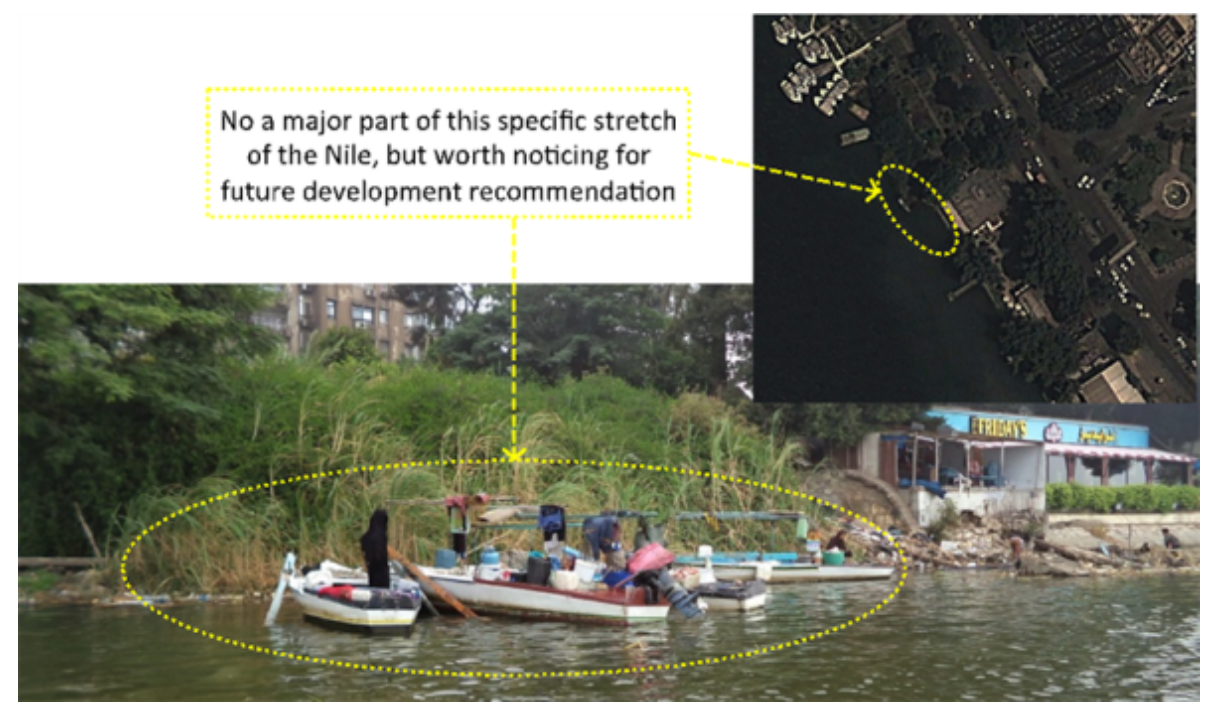

Fig. 19. Family living permanently on the Nile

\subsubsection{Noise}

In a congested traffic and crowded city such as Cairo, and especially on such a main spine of movement parallel to the Nile, noise becomes an important factor to inform landscape designers on where to locate services, trails, activities and landscape features. In this stretch of the Nile, I 5 different cross sections along the study area were identified based on the horizontal changes that occur in the morphology of the river and the main street. Three different measures were taken for each cross section, one on the street, one on the bank edge and one along the water. The street measures' varied from 86 to 92 decibels, the banks vary from 70 to 79 decibels and the measures at the water varied from 60 to 72 decibels. Figure 20 shows the map identifying the location in which the measures were taken, and the diagram shows the changes along the different sections for the three different zones ${ }^{2}$.

\footnotetext{
' Measures were taken in at 3pm for three hours on two days; another check was done at early morning on few points. The noise was less but the variation was almost constant.

${ }^{2}$ The readings taken did not include night measures, which is a limitation that needs further exploration in the upcoming site visit.
} 

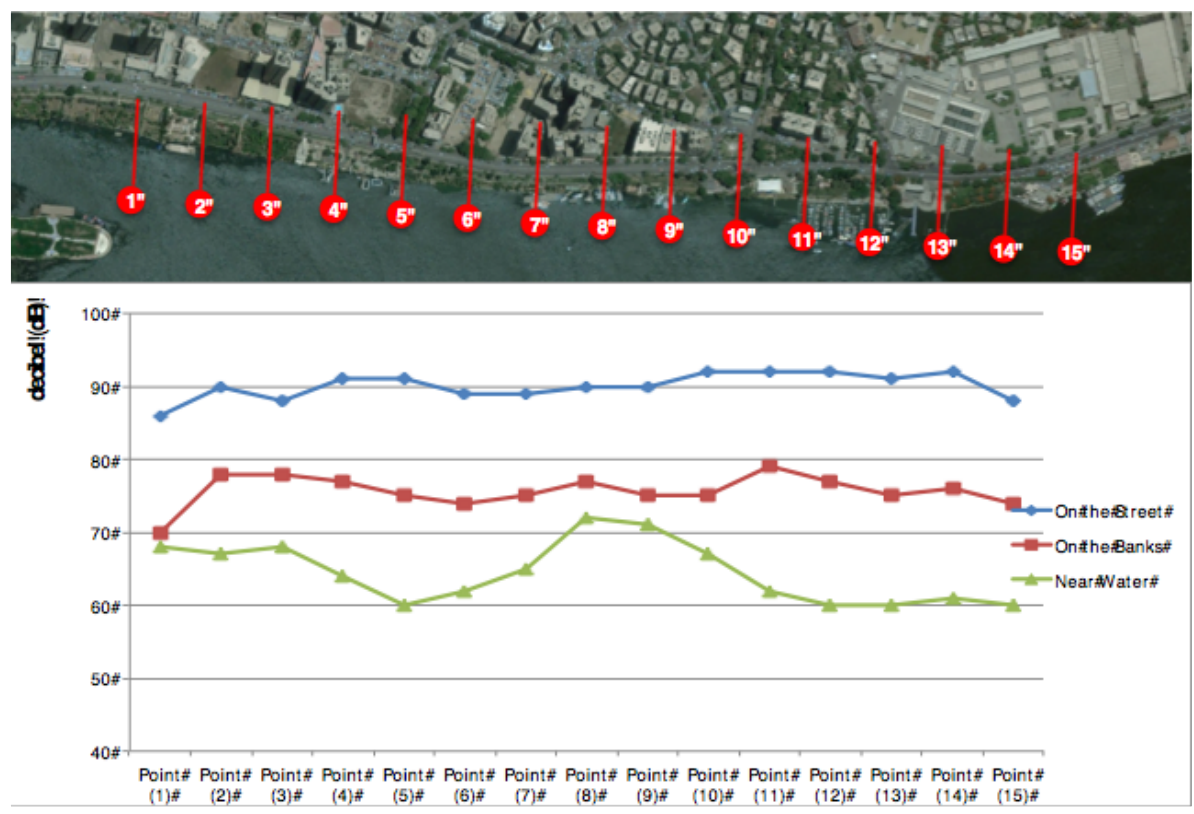

Fig. 20. The three curves represent the change in noise, surveyed along the study area.

\subsubsection{Under-utilized parts of the banks}

Under-utilized lands are stretches of the banks that are used as dumping sites or informal storage/collection for unused boats. These are, according to the interview with Mr Farag, are owned by speculators who have several businesses and just maintaining those stretches as real estate to re-activate them when the economy improves as shown in figure 21 .

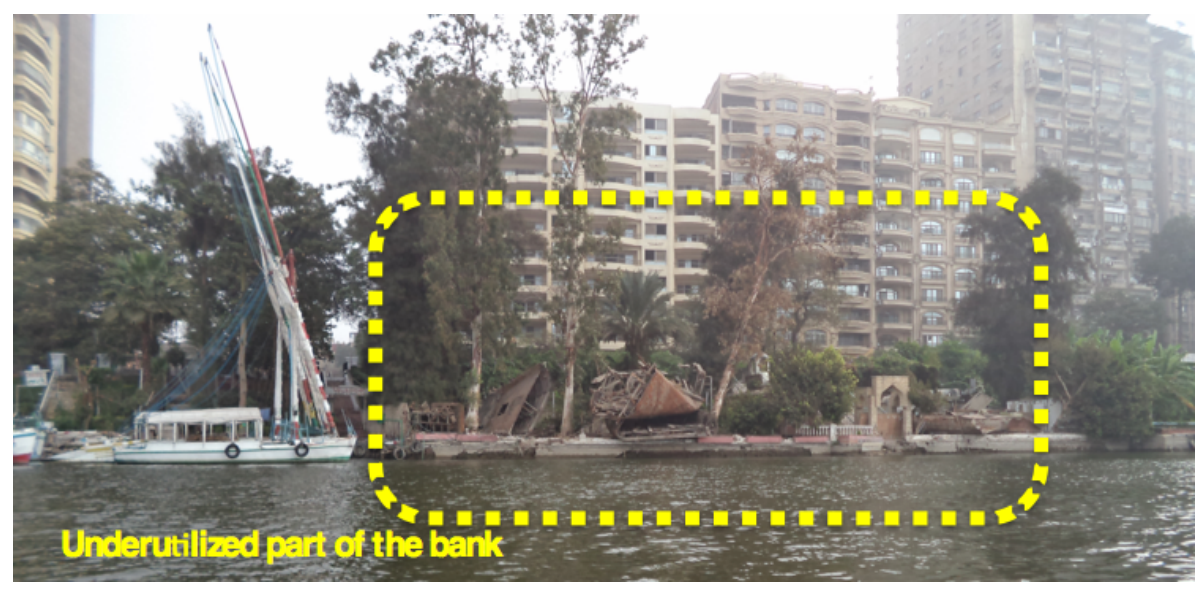

Fig. 21. Image showing an underutilized land and now used as dump site for useless boats parts

\subsubsection{Concrete Banks}

The field survey showed that urbanization is invading the river on two scales: (i) the mega urban development (i.e. towers) prevents the possibility to any provision to support river meandering naturally even slightly and limit its original interaction with the land; and (ii) 
the concretization of the river edges kills the river's ability to restore its natural process of the banks including restoring riparian vegetation, sedimentation or erosion process. Figure 22 shows the edges of Al-Yacht Club and Al-Adra church both being built to the water by concrete.
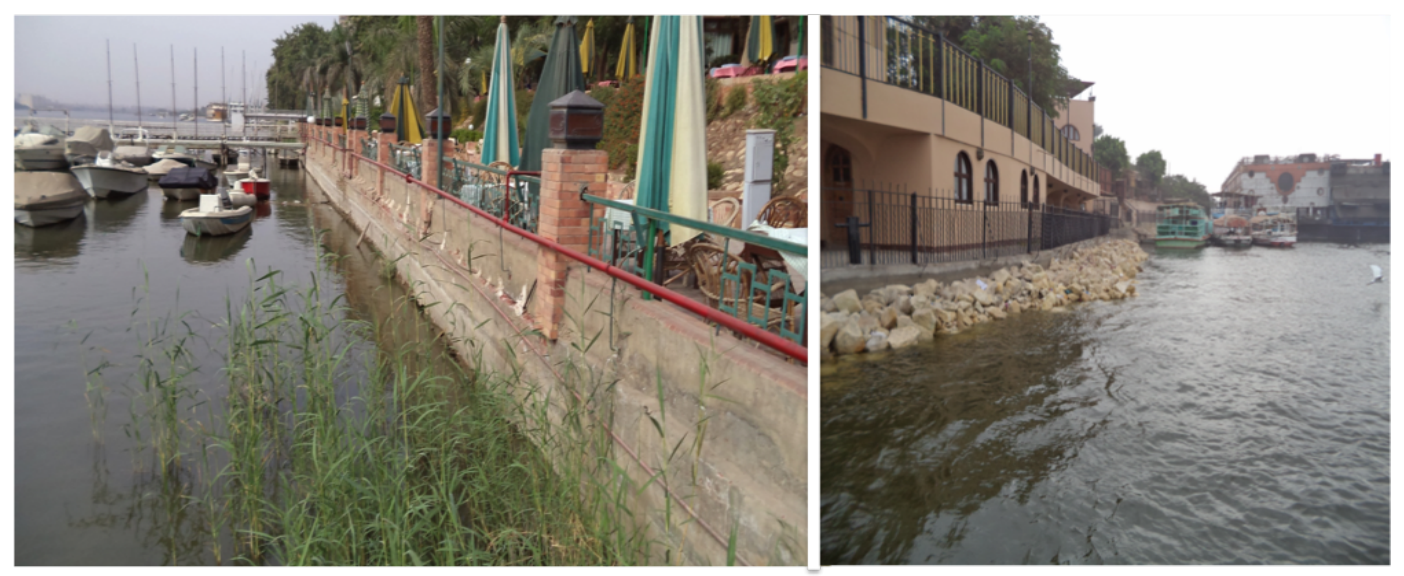

Fig. 22. Example of river edge with highly urbanized concrete banks (to the left al-Yacht club looking north and to the right al-Adra church looking south).

\section{Results and discussions}

When overlaying the entire layers of survey, as in figure 23 , the following were the main findings:

- Native vegetation will likely grow if given the opportunity to be restored. Since existing bank with riparian vegetation zone is not eroded, encouraging the vegetation restoration will help stabilize the banks in the case of removing the concrete platforms. In addition, the floating Nile cruises are problematic to the remaining ecological process (sedimentation and erosion) and it is likely that the banks will gain more breadth and interaction with the water if the cruises are removed or reduced. The restoration of the native plants will act as a natural protection in the areas of high rate of erosion.

- Public access is found to be a concern as it is limited in relation to the opportunity provided. If, for example, we consider individuals wanting to pursue fishing as a hobby that require direct contact with the river, the calculation of the fieldwork showed that more than half of the stretch (55\%) is not accessible for public. It is either blocked by military establishment, government facilities or private business.

- The Nile is underutilized as transportation corridor since it is a long river flowing through the city, it has the potential to be one of its main sources of longitudinal and lateral transportation corridors, and this will certainly reduce the pressure on the metro and the car traffic on the asphalt road parallel to the river.

- The banks have some (unused lands) that have potential for natural restoration and growing natural vegetation. The example represented in this segment, according to the interview with Mr. Farag, a boat operator who has been on the banks for 22 years, is that the owner had gone bankrupt and with no restrictions from the government to obtain the land back, it remained and transformed to a dump site for old boats or useless broken parts. 
- Observations show that few families living on the Nile in floating boats (fishing), which constitute a source of pollution. Currently not extremely significant in the study area, the phenomenon is known to be common near the island and in other stretches of the Nile, but fieldwork shows that it started to appear in Maadi. It is part of an economic degradation in the city and need to be addressed in conjunction with informal settling in Cairo.

\section{Conclusion and recommendation}

Although the river cannot be restored to its full ecological integrity as explained earlier, the potential to achieve better ecological conditions for the river, the banks and its surrounding communities is doable. This can be achieved through the following recommendations in the plan in figure (24).

a) group the marine operations into two jetties (i) the one the ferry is currently using to be the selected one for the motor boating, and (ii) the yacht club marina to be the one that hosts the sailing boats (not noisy and not polluting). This shall allow healthy restoration, even partially, of the riverbanks;

b) connect public spaces together in a form of trail that can support pedestrian movement along the Nile;

c) removing the concrete edges and stabilizes the banks by restoring native vegetation. Provide guidelines for bank users to gradually replace other trees with the identified Nile species;

d) propose concentration of native vegetation between the sitting areas near the water and the main street to provide shade, improving micro-climate and enhance aesthetic quality. The integration between the river plans and the inland landscape increases the ecological improvements;

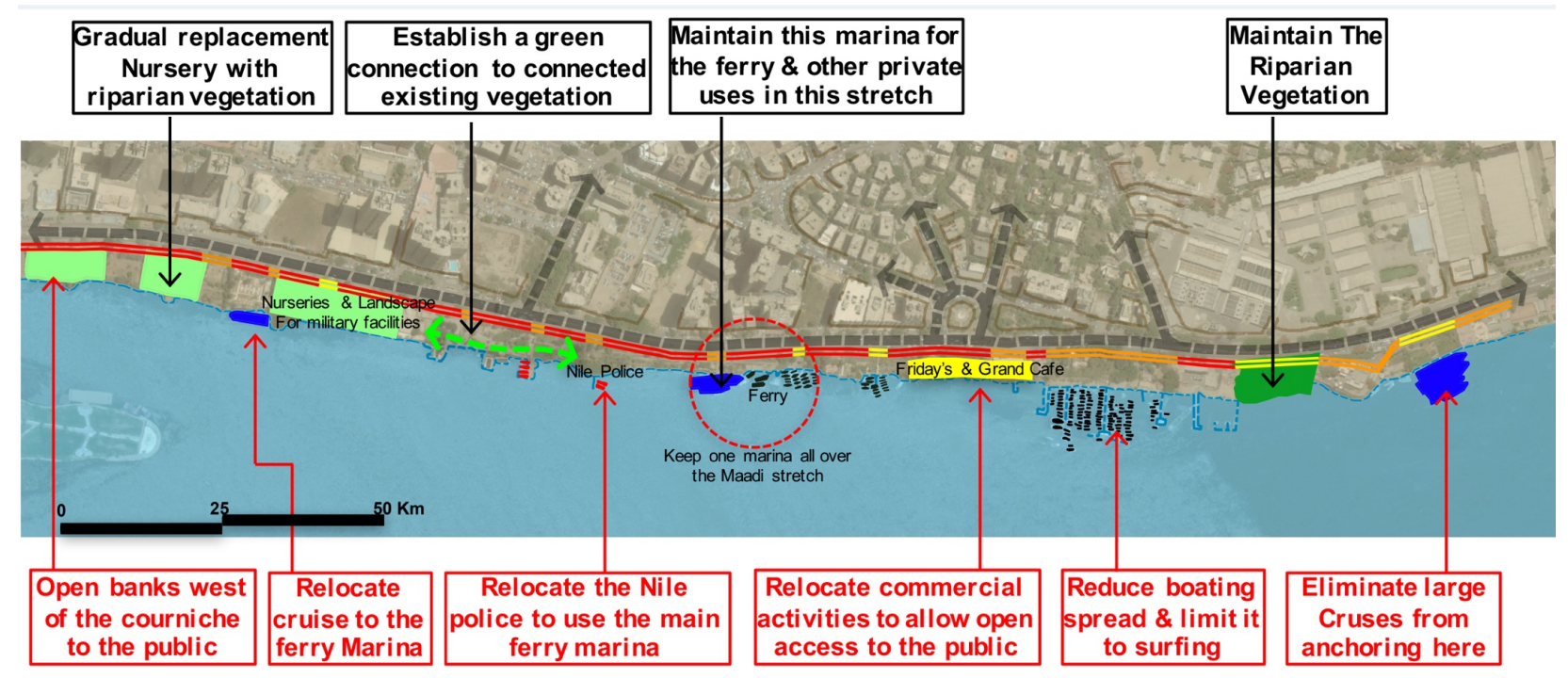

Fig. 23. Overlaid analysis - the black shows aspects to be maintained and supported, and the red shows the aspects that needs to change.

46 | The Journal of Public Space, 3(I), 20I8 | ISSN 2206-9658

City Space Architecture / Queensland University of Technology / UN-Habitat 


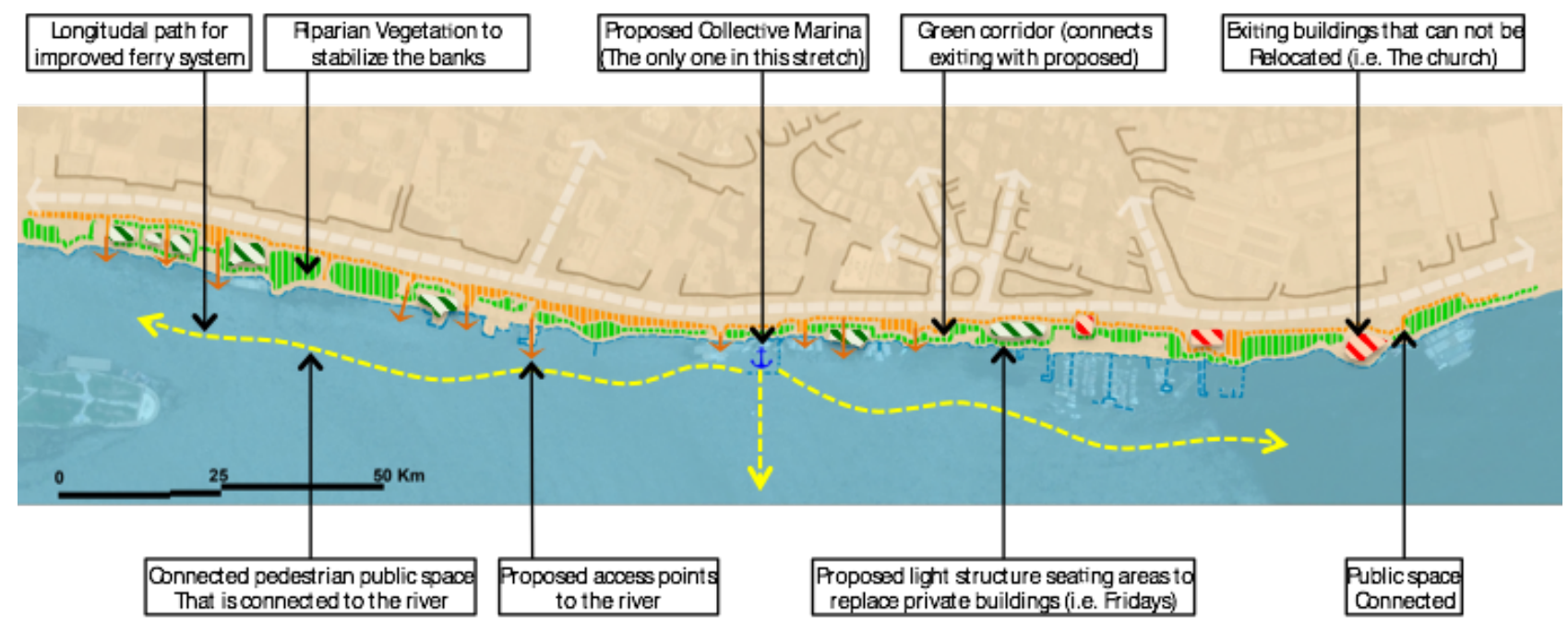

Fig. 24. Proposed schemes for the study area with the set of recommendations

e) reuse the under-utilized properties along the banks, not by opening it for other (private) business, but by making use of its potential to be an accessible public space;

g) as much as possible, allow access to the river by linking the main proposed path along the banks with the river to allow access. These access points shall be through: (i) the under-utilized lots that will be open for public, or (ii) the relocation of some government establishment such as military facilities, and (iii) modify regulations of private uses such as restaurants to allow better public interaction with the river. This shall upgrade the semi public to public increasing the length of the public access stretches from $16 \%$ to $45 \%$ of this total representative stretch as phase one of the gradual modifications;

h) maximize the utilization of the river as a water corridor by developing a business model for the ferries, improve its conditions, integrate it with other modes of transportation and advertise for its use along wide range of Egyptians.

Figure 25 shows the proposed alignment for the pedestrian path, which is proposed in suitable areas that are sometimes on the street pavement and other times right by the water. The same illustration shows the potential area for vegetated zones as green network that include the exiting riparian vegetation and other potential for green open spaces.

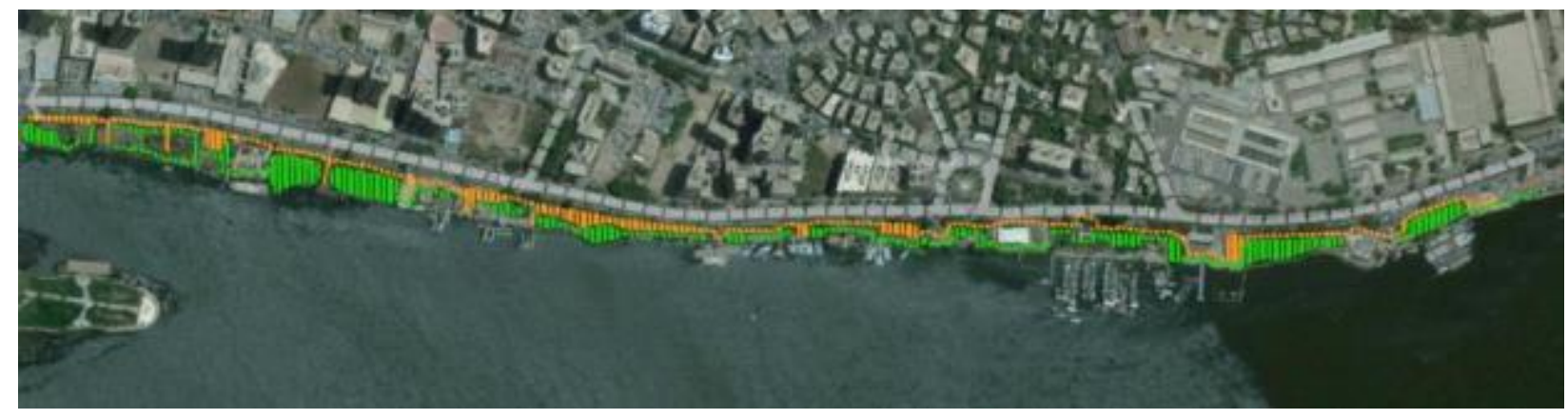

Fig. 25. Potential connection for pedestrian path and green vegetation corridor. 
Greening and opening the public space of the Nile banks

\section{References}

Abu-Zeid, M., \& El-Shibini, F. Z. ( 1997$)$. Egypt's High Aswan Dam. International Journal of Water Resources Development, I3(2), 209-2 I8. http://doi.org//0.1080/07900629749836.

AlSayyad, N. (20I I). Cairo: Histories of a City. Retrieved from http://www.amazon.com/CairoHistories-City-Nezar-AlSayyad/dp/0674072456.

Bernhardt, E., \& Palmer, M. (2007). Restoring streams in an urbanizing world. Freshwater Biology, 52(4), 738-75I. http://doi.org/I0.IIII/j.1365-2427.2006.017/8.x.

Booth, D. (2005). Challenges and prospects for restoring urban streams : a perspective from the Pacific Northwest of North America. The North American Benthological Society, 24(3), 724737.

El-Shibini, F. Z., \& Rydzewski, J. R. (1977). Towards an optimal utilization of the water resources of the Nile Basin, 35-47.

El Araby, M. (2002). Urban growth and environmental degradation: The case study of Egypt. Cities, 19(6), 389-400. http://doi.org/I0.1016/S0264-275I(02)00069-0.

Gabr, H. S. (2004). Perception of Urban Waterfront Aesthetics Along the Nile in Cairo, Egypt. Coastal Management, 32(2), I55-17I. http://doi.org/I0.1080/08920750490276191.

Gohar, A. (2016). Greening and Opening the Banks of The Nile: A proposed demonstration project in Maadi, Cairo. Middle East Studies Association.

Kassas, M. (197I). The River Nile Ecological System: A Study Towards an International Programme, 4(I).

Kondolf, G. M., Mozingo, L., Gohar, A., \& Marzion, R. (20I I). Connecting Cairo to the Nile: Renewing Life and Heritage on the River. Institute of Urban \& Regional Development, I I 2.

Kondolf, M., Gohar, A., Mozingo, L., Marzion, R., \& Balakrishan, K. (20I3). Connecting Cairo to the Nile: Opportunities for Public Access and Alternative Transportation. Democratic Transition and Sustainable Communities.

Mahdy, H. (20I2). Towards Reliable Public Bus Services in Greater Cairo, 2(3), I65-176. Retrieved from https://www.researchgate.net/publication/268393002_Towards_Reliable_Public_Bus_Service $s$ in Greater Cairo.

Malone, K. (2002). Street life: youth, culture and competing uses of public space. Environment and Urbanization, 14(2), 157-I68. http://doi.org/I0.1 I77/09562478020I4002I3.

Mehta, V. (2014). Evaluating Public Space. Journal of Urban Design, 19(I), 53-88, http://doi.org// 0.1080//3574809.2013.854698.

Rosenberg, M. (2017). Aswan High Dam. Retrieved from https://www.thoughtco.com/aswan-highdam- 1435554 .

Sabry, S. (2010). How poverty is underestimated in Greater Cairo, Egypt. Environment and Urbanization, 22(2), 523-54I. http://doi.org/I0.I I77/09562478I0379823.

Sims, D. (20I2). Understanding Cairo: The Logic of A City Out of Control. Cairo: American University Press.

Zhang, M. (2016). Quality Urban Public Space for Quality of Life. South Asia.

48 | The Journal of Public Space, 3(I), 20I8 | ISSN 2206-9658

City Space Architecture / Queensland University of Technology / UN-Habitat 